\title{
Congenital Dyserythropoietic Anemia Type IV
}

National Cancer Institute

\section{Source}

National Cancer Institute. Congenital Dyserythropoietic Anemia Type IV. NCI Thesaurus.

Code $C 157148$

An autosomal dominant sub-type of congenital dyserythropoietic anemia caused by mutation(s) in the KLF1 gene, encoding Krueppel-like factor 1. 